\title{
The trace element chemistry of titanite varies with host rock lithology
}

\section{ELISABETH SCIBIORSKI ${ }^{1}$ AND PETER A CAWOOD ${ }^{2}$}

\author{
${ }^{1}$ Monash University \\ ${ }^{2}$ Monash University \\ Presenting Author: elisabeth.scibiorski@monash.edu
}

The trace element composition of titanite reflects the pressure, temperature and bulk-rock composition at which it crystallised. Three simple geochemical discriminators are identified by applying a machine learning classifier to a global compilation of titanite trace element data. First, igneous and metamorphic titanite are shown to differ in $\mathrm{Al} / \mathrm{Fe}$ ratio and $\sum$ LREE content. Variations in $\mathrm{Th} / \mathrm{U}$ ratio and crystal zoning aid discrimination where both igneous and metamorphic titanite are present, such as deformed igneous rocks. Second, titanite from felsic host rocks is characterised by low $\mathrm{Zr} / \mathrm{Y}$ and high Fe content. For titanite from igneous rocks, this effectively discriminates titanite from mafic and felsic rocks. Finally, the $\mathrm{Zr}$ and $\mathrm{Al}$ content of metamorphic titanite can be used to estimate the P-T conditions of crystallisation. Together, these geochemical discriminators may be used to identify the host rock of an unknown titanite, a valuable tool with applications in fields such as petrochronology and detrital provenance analysis. 